\title{
PENGEMBANGAN PERANGKAT LUNAK DETEKSI GAMBAR PORNO DI BROWSER PENGGUNA INTERNET
}

\author{
Bambang Sugiantoro, Rischan Mafrur, Nur Sholahudin Fajri \\ Program Studi Teknik Informatika Fakultas Sains dan Teknologi Universitas Islam Negeri Sunan \\ Kalijaga Jl Marsda Adisucipto Yogyakarta \\ bambang.sugiantoro@uin-suka.ac.id
}

\begin{abstract}
ABSTRAK
Penelitian ini merupakan implementasi dari algoritma poligon aplikasi Node.js dalam bentuk add-on Mozilla Firefox (inetfilter). Algoritma Nude.js ditulis oleh Patriek Wied kemudian juga diuji dalam sebuah penelitian yang dilakukan oleh Rigan Ap-apid, dalam studinya mengatakan bahwa algoritma ini memiliki kinerja yang lebih baik daripada SVM, WIPE, Jones-Rehg, Fleck- Forsyth dalam hal deteksi gambar-gambar porno. Penelitian yang dilakukan oleh Rigan Ap-apid menggunakan data pelatihan dan pengujian yang telah dikumpulkan dengan jumlah 421 dan 635 gambar porno bukan gambar porno dengan ukuran gambar tidak disebutkan. Penelitian ini akan menggunakan data yang lebih nyata dalam bahwa data langsung dari pencarian menggunakan mesin pencari. Studi ini menambahkan fungsi multi-deteksi pada nude.js perpustakaan kemudian diimplementasikan dalam bentuk add-on Mozilla Firefox. Pengujian dilakukan dengan menggunakan browser Firefox add on inetfiter sudah terpasang. Pengujian dilakukan dengan menggunakan 14 kata kunci dalam pencarian menggunakan mesin pencari google pada gambar, halaman depan dua situs porno terkenal, dan satu halaman dengan 40 gambar. Rincian jumlah gambar adalah 4733 pornografi gambar seperti: Miyabi, Maria Ozawa, Nude, Naked, dll, 894 gambar dengan dua kata kunci bertema non-porno seperti: sapi, wajah, dll, 95 gambar dari halaman dua situs porno terkenal, dan 40 gambar dari halaman yang dibuat oleh peneliti sendiri. Jumlah gambar yang diuji adalah 5762 gambar dengan 4010 gambar gambar porno diprediksi. Total gambar terdeteksi gambar porno adalah 3276. Demikian hasil tes menyimpulkan bahwa menambahkan pada inetfilter mampu mendeteksi $81,70 \%$ dengan error deteksi gambar porno dari $13,72 \%$.
\end{abstract}

Kata kunci: pornografi, gambar porno, deteksi gambar porno

\begin{abstract}
This research is an implementation of the algorithm polygon node.js applications in the form of addon Mozilla Firefox (inetfilter). Nude.js algorithm is written by Patriek Wied then also be tested in a study conducted by Rigan Ap-apid, in the study said that this algorithm has better performance than SVM, WIPE, Jones-Rehg, Fleck- Forsyth in case of detection of pornographic images. Research conducted by Rigan Ap-apid using training data and the testing that has been collected with the number 421 and 635 pornographic images is not a pornographic image by image size is not mentioned. This study will use data that is more real in that the data directly from the search using search engines. This study adds multi-detection function on the library nude.js then implemented in the form of add-on Mozilla Firefox. Tests were performed using the Firefox browser add on inetfiter already installed. Testing was performed using 14 keywords in a search using google search engine on the pictures, the front page of two famous porn sites, and one page with 40 pictures. Details of the number of images is a 4733 picture pornography such as: Miyabi, Maria Ozawa, Nude, Naked, etc., 894 images with two keywords themed non-pornographic such as: cow, face, etc., 95 images of page two sites famous porn, and 40 images of pages created by the researchers themselves. Total of images tested were 5762 image with the 4010 image predictable pornographic pictures. Total images detected pornographic image is 3276 . Thus the test results concluded that the add on inetfilter able to detect $81.70 \%$ with a pornographic image detection error of $13.72 \%$.
\end{abstract}

Key words: pornography, pornographic pictures, pornographic image detection 


\section{PENDAHULUAN}

Saat ini hampir tidak ada orang yang tidak kenal dengan internet, setiap hari kita berhubungan dengan internet. Internet tidak hanya menjadi sebuah kebutuhan melainkan sudah menjadi gaya hidup.Internet membawa dampak positif yaitu berupa kemudahan dalam komunikasi, kemudahan dalam akses informasi dan sebagainya tetapi dibalik itu semua, internet juga seperti pisau yang bermata dua, internet juga membawa banyak keburukan salah satunya pornografi. Saat ini seorang anak kecil bisa saja pergi ke warung internet (warnet), dengan hanya membawa uang dua ribu rupiah sudah bisa mengakses pornografi secara gratis, sungguh sangat memilukan. Tidak hanya sampai disitu, sebagai contoh pengalaman pribadi kami sendiri, suatu ketika kami mengetikan sebuah keyword di search engine yang tidak berhubungan dengan pornografi tetapi yang muncul gambar atau iklan yang mengarah ke hal pornografi.

Sudah ada beberapa cara yang biasanya digunakan untuk mencegah pornografi, yang paling umum dengan metode block keyword/ dictionary, block domain dan IP di IP Tables atau seperti nawala project yang menggunakan DNS filtering. Penggunaan IP Tables dengan menge-block keyword yang berhubungan dengan pornografi dan juga situssitus yang sudah terdaftar ataupun menggunakan DNS sendiri seperti yang dilakukan oleh nawala project itu kurang efektif. Bisa jadi seorang mahasiswa atau pelajar jurusan biologi ketika dia membutuhkan sebuah informasi berkaitan dengan "sex" misalnya maka otomatis dia tidak bisa mengaksesnya. Bahkan saat ini para pembuat situs pornografi sudah begitu cerdas, memberikan nama situsnya dengan nama yang tidak ada hubunganya sama sekali dengan pornografi, contohnya lalatx.com dan sebagainya. Sekarang tidak sedikit iklan di website atau blog yang menampilkan gambargambar yang tidak layak untuk dilihat oleh anak yang tentunya ini juga susah untuk di antisipasi menggunakan cara-cara tersebut.

Berdasarkan alasan tersebut peneliti mengusulkan menggunakan metode lain yaitu pendeteksi dengan digital image processing, dalam penelitian ini lingkupnya yaitu pendeteksian gambar porno dengan image processing. Ketika seseorang mencari informasi di internet kemudian ada gambar porno maka otomatis gambar itu akan disilang atau digantikan dengan gambar lain tanpa menge-block semua konten atau tulisan yang ada. Penelitian ini mengimplementasikan digital image processing untuk pendeteksian dan penge-block-an gambar porno dalam bentuk tool berbetntuk add-ons yang dapat dipasang di browser Mozilla Firefox yang kami namai inetfilter.

\section{LANDASAN TEORI 2.1.1 Citra Digital}

Citra adalah suatu representasi (gambaran), kemiripan, atau imitasi dari suatu objek.Citra terbagi 2 yaitu ada citra yang bersifat analog dan ada citra yang bersifat digital. Citra analog adalah citra yang bersifat kontinu seperti gambar pada monitor televisi, foto sinar X, hasil CT Scan dll. Sedangkan pada citra digital adalah citra yang dapat diolah oleh komputer (Sutoyo et al. 2009: 9). Sebuah citra digital dapat mewakili oleh sebuah matriks yang terdiri dari $\mathrm{M}$ kolom $\mathrm{N}$ baris, dimana perpotongan antara kolom dan baris disebut piksel (pixel = picture element), yaitu elemen terkecil dari sebuah citra. Piksel mempunyai dua parameter, yaitu koordinat dan intensitas atau warna. Nilai yang terdapat pada koordinat $(\mathrm{x}, \mathrm{y})$ adalah $\mathrm{f}(\mathrm{x}, \mathrm{y})$, yaitu besar intensitas atau warna dari piksel di titik itu (Sutoyo, 2009)

\subsubsection{Pengolahan Citra Digital}

Pengolahan citra digital adalah sebuah disiplin ilmu yang mempelajari hal-hal yang berkaitan dengan perbaikan kualitas gambar (peningkatan kontras, transformasi warna, restorasi citra), transformasi gambar (rotasi, translasi, skala, transformasi geometrik), melakukan pemilihan citra ciri (feature images) yang optimal untuk tujuan analisis, melakukan proses penarikan informasi atau deskripsi objek atau pengenalan objek yang terkandung pada citra, melakukan kompresi atau reduksi data untuk tujuan penyimpanan data, transmisi data, dan waktu proses data. Input dari pengoalahan citra adalah citra, sedangkan outputnya adalah citra hasil pengolahan.

\subsubsection{Pornografi}

Pornografi berasal dari kata Yunani yaitu "porne" yang berarti pelacur dan "grape" yang berarti tulisan atau gambar. Jadi pengertian pornografi sebenarnya lebih menunjuk pada segala karya baik yang 
dituangkan dalam bentuk tulisan atau lukisan yang menggambarkan pelacur (Armando, 2004).

Dalam konteks hukum konsep mengenai pornografi dapat juga ditemukan dalam beberapa ketentuan perundangundangan. Dalam KUH Pidana, misalnya walaupun di sana tidak menyebutkan secara eksplisit mengenai apa definisi pornografi tersebut. Batasan atau hal yang dapat dipersamakan dengan pengertian pornografi dalam KUH Pidana hanyalah disebut sebagai kejahatan terhadap kesusilaan atau kejahatan terhadap kesopanan. Namun jika dilihat dari bentuk-bentuk kejahatan yang diatur dalam KUH Pidana tersebut, maka kesemuanya termasuk dalam kategori pornografi. Walaupun demikian berdasar pada pengertian tentang apa yang dimaksud dengan kesopanan atau kesusilaan menunjukkan dalam KUH Pidana tidak terdapat adanya legalisasi yang mengatur masalah pornografi. Konsep pornografi menurut Undang-Undang No. 40 Tahun 1999 tentang Pers menyebutkan dalam Pasal 13 huruf a bahwa perusahaan pers dilarang memuat iklan yang berakibat merendahkan martabat suatu agama dan atau menganggu kerukunan hidup antar umat beragama, serta bertentangan dengan rasa kesusilaan masyarakat. Disini format yang digunakan sebagai batasan adalah rasa kesusilaan masyarakat tanpa merinci apa yang dimaksud dan cakupan rasa kesusilaan meliputi hal apa saja. Dengan demikian sama halnya dengan KUH Pidana, Undang-Undang Pers juga tidak cukup menjelaskan apa yang dimaksud dengan pornografi tersebut. Dalam Undang-Undang No. 23 Tahun 2002 tentang Perlindungan Anak tidak juga menyebutkan secara eksplisit kata pornografi, namun secara tersirat undang-undang ini-sebagaimana dimuat dalam Pasal 13 ayat (1) huruf (b)menunjuk adanya bentuk-bentuk eksploitasi seksual atas anak yang mengarah pada pornografi. Dengan demikian dari beberapa ketentuan perundang-undangan tersebut di atas, konsep pornografi masih dirumuskan secara sangat umum dan tidak detail sehingga cenderung mengundang berbagai interpretasi (multi interpretasi) dengan demikian menjadi tidak mampu secara maksimal menjerat bentuk-bentuk tindak pidana pornografi yang terjadi.

Dari berbagai referensi yang penulis sebutkan dan juga dari beberapa referensi yang penulis baca memang definisi pornografi memang belum jelas sehingga itu cukup menyusahkan. Akan tetapi definisi umum yang biasanya dipakai oleh beberapa vendor aplikasi untuk membuat sebuah tool yang digunakan untuk block gambar porno adalah ketika gambar tersebut menampilkan bagian-bagian intim tubuh seseorang baik sendiri, berdua atau beberapa orang.

\subsubsection{Mozilla Firefox Add-ons}

Berkembangnya teknologi web yang saat ini sudah mencapai versi web 3 kemudian teknologi HTML 5, cloud computing dan sebagainya memberikan titik terang bahawa sepertinya teknologi masa depan adalah teknologi web dan cloud. Saat ini browser tidak hanya digunakan untuk browsing beberapa vendor seperti Mozilla dan juga Google sebagai pembuat browser google chrome merilis operating system berbasis browser. Tahun 2011 Firefox adalah browser yang paling banyak digunakan kemudian tahun 2012 Firefox dikalahkan oleh Google Chrome, pada tahun 2013 ini Google Chrome adalah browser paling unggul dengan pengguna sebanyak $48.4 \%$ disusul oleh Firefox dengan jumlah pengguna $30.2 \%$ [5].

Peneliti memutuskan untuk menggunakan add ons Mozilla firefox dikarenakan saat ini peneliti belum memiliki kemampuan untuk membuat extention untuk browser chrome. Sehingga yang kami pilih adalah firefox.Jika implementasi dan pengujian ini berhasil sukses tidak menutup kemungkinan bagi peneliti untuk mengimplementasikan algoritma ini dalam bentuk Google Chrome extension.

Firefox Add-ons merupakan sebuah aplikasi tambahan yang dapat diinstal pada web browser untuk dapat memudahkan suatu pekerjaan. Aplikasi pada FirefoxAdd-ons menggunakan bahasa XUL dan XPCOM yang berbasis javascript[6].

\subsubsection{Nude.js}

Nude.js adalah library yang ditulis oleh Patrick Weid dengan yang dapat digunakan untuk klasifikasi gambar porno, library ini ditulis menggunakan javascript. Library ini dirilis open source September 2011 dengan lisensi MIT.Peneliti memutuskan daripada membuat library dari awal lebih baik menggunakan library yang sudah ada dan tentunya juga memberikan kontribusi terhadap 
library tersebut. Peneliti tertarik menggunakan library ini karena sudah dilakukan penelitian sebelumbya oleh Rigan Ap-apid, dalam penelitian tersebut dikatakan bahwa algoritma ini punya performa yang lebih baik daripada SVM,WIPE, Jones-Rehg, Fleck-Forsyth dalam hal deteksi gambar porno Peneliti ingin mencoba mengimplementasikan dan menguji dengan data yang lebih real yaitu dengan membuat Add-ons firefox dengan library tersebut. Library ini menggunakan pendeteksian kulit secara poligon. Setiap gambar akan dicari empat titik yaitu atas, bawah, kanan, dan kiri kemudian akan dicari prosentase kulit di sekitar titik-titik berikut.

\subsubsection{JQuery}

JQuery merupakan suatu framework (library) Javascript yang menekankan bagaimana interaksi antara Javascript dan HTML.JQuery pertama kali dirilis pada tahun 2006 oleh John Resig.Pada perkembangannya JQuery tidak sekedar sebagai framework Javascript, namun memiliki kehandalan dan kelebihan yang cukup banyak. Hal tersebut menyebabkan banyak developer web menggunakannya. JQuery memiliki slogan "Write less, do more" yang kurang lebih maksudnya adalah kesederhanaan dalam penulisan code, tapi dengan hasil yang lebih banyak.

JQuery biasanya di-include-kan dalam pembuatan web, atau untuk proses transaksi data dan sebagainya. Penelitian ini menggunakan JQuery karena library nude.js hanya support untuk deteksi gambar per satu gambar. Sehingga peneliti harus menambahkan kode yang berfungsi untuk melakukan scan seluruh gambar dalam satu halaman web. Setiap gambar akan diperiksa kemudian akan diklasifikasi apakah gambar tersebut kategori gambar porno atau tidak. Jika gambar tersebut kategori gambar porno maka gambar tersebut akan diganti dengan gambar lain.

Kode yang peneliti gunakan agar nude.js mendukung untuk banyak gambar yaitu peneliti mengenerate id dari semua gambar yang ada dalam setiap halaman dan tentunya dalam proses generate id tersebut peneliti menggunakan library JQuery.

\section{PEMBAHASAN DAN HASIL PENELITIAN}

\subsubsection{Hasil Uji Coba Add-ons inetfilter}

Pengujian add-ons langsung dilakukan menggunakan data gambar hasil dari internet. Peneliti menggunakan 12 kata kunci yang berhubungan dengan pornografi di search engine google. Kata kunci tersebut adalah Maria Ozawa, Miyabi, Man Naked, Nude, Nude Women, Body Women close up, Women Topless, Hot Pose, Naked Women, Sexy Women, Sex,Pamela Anderson, dari 12 kata kunci ini terkumpul sejumlah 4733 gambar dengan 3890 gambar diprediksi gambar porno dan 843 bukan gambar porno. Dua kata kunci yang tidak berhubungan dengan pornografi yaitu wajah dan sapidari kata kunci ini ada 894 gambar dan ternyata dari pencarian dengan kata kunci sapid an wajah ada 5 gambar yang peneliti kategorikan sebagai gambar porno. Dua halaman depan dari dua situs porno terkenal ada 63 dan 32 gambar porno kebanyakan dalam bentuk close up. Satu halaman depan yang terdiri dari 40 gambar dengan 20 gambar porno (full body polygon) dan 20 gambar bukan porno yang peneliti buat sendiri. Hasil penelitian dapat dilihat pada Tabel 1. 
Tabel 1. Hasil Pengujian Add-ons inetfilter

\begin{tabular}{|c|c|c|c|c|c|c|c|c|c|c|}
\hline \multirow{3}{*}{ No } & \multirow{3}{*}{ Keyword } & \multicolumn{4}{|c|}{ Jumlah Gambar } & \multirow{3}{*}{$\begin{array}{c}\text { Total } \\
\text { terdeteksi }\end{array}$} & \multirow{3}{*}{$\begin{array}{l}\text { Prediksi } \\
\text { Porno }\end{array}$} & \multirow{3}{*}{$\begin{array}{c}\text { Total } \\
\text { Gambar }\end{array}$} & \multirow{3}{*}{$\begin{array}{c}\text { Prosentase }(\%) \\
\text { terdeteksi/prediksi }\end{array}$} & \multirow[b]{3}{*}{ Error $(\%)$} \\
\hline & & \multicolumn{2}{|c|}{ Bentuk Poligon } & \multicolumn{2}{|c|}{ Bentuk Bebas } & & & & & \\
\hline & & $\begin{array}{l}\text { Terde } \\
\text { teksi }\end{array}$ & $\begin{array}{c}\text { Tidak } \\
\text { Terdeteksi }\end{array}$ & Terdeteksi & $\begin{array}{c}\text { Tidak } \\
\text { Terdeteksi }\end{array}$ & & & & & \\
\hline 1 & Maria Ozawa & 242 & 58 & 14 & 89 & 256 & 380 & 403 & 67.37 & 5.00 \\
\hline 2 & Miyabi & 261 & 49 & 2 & 98 & 263 & 380 & 410 & 69.21 & 5.00 \\
\hline 3 & Man Naked & 278 & 38 & 5 & 69 & 283 & 300 & 390 & 94.33 & 6.00 \\
\hline 4 & Nude & 291 & 49 & 7 & 83 & 298 & 350 & 430 & 85.14 & 4.00 \\
\hline 5 & Nude Women & 220 & 52 & 16 & 92 & 236 & 300 & 380 & 78.67 & 7.00 \\
\hline 6 & Body Women close up & 220 & 49 & 12 & 79 & 232 & 260 & 360 & 89.23 & 5.00 \\
\hline 7 & Women Topless & 244 & 37 & 18 & 93 & 262 & 350 & 392 & 74.86 & 5.00 \\
\hline 8 & Hot Pose & 258 & 51 & 3 & 90 & 261 & 340 & 402 & 76.76 & 5.00 \\
\hline 9 & Naked Women & 233 & 62 & 4 & 80 & 237 & 300 & 379 & 79.00 & 5.00 \\
\hline 10 & Sexy Women & 289 & 39 & 6 & 83 & 295 & 350 & 417 & 84.29 & 5.00 \\
\hline 11 & Sex & 273 & 40 & 7 & 74 & 280 & 300 & 394 & 93.33 & 5.00 \\
\hline 12 & Pamela Anderson & 247 & 28 & 4 & 97 & 251 & 280 & 376 & 89.64 & 5.00 \\
\hline 13 & Situs Redtube.com & 12 & 2 & 1 & 48 & 13 & 63 & 63 & 20.63 & 79.36 \\
\hline 14 & Situs Youporn.com & 6 & 3 & 2 & 21 & 8 & 32 & 32 & 25.00 & 75.00 \\
\hline 15 & Membuat Sendiri & 20 & 0 & 0 & 20 & 20 & 20 & 40 & 100.00 & 0.00 \\
\hline 16 & Gambar Wajah (Google) & 0 & 0 & 34 & 396 & 34 & 2 & 430 & 0.00 & 7.44 \\
\hline \multirow[t]{2}{*}{17} & Gambar Sapi (Google) & 0 & 0 & 47 & 417 & 47 & 3 & 464 & 0.00 & 9.48 \\
\hline & Total & 3094 & 557 & 182 & 1929 & 3276 & 4010 & 5762 & 81.70 & 13.72 \\
\hline
\end{tabular}


Dari Tabel 1. terlihat bahwa sepesifikasi algoritma nude.js adalah pada gambar porno dengan bentuk poligon yaitu satu orang di tengah sebagai fokus sehingga gambar-gambar dari situs youporn dan redtube sedikit yang berhasil terdeteksi sebagai gambar porno padahal tentu hampir semua gambar di situ adalah gambar porno. Di samping itu error terjadi sangat besar yaitu $79.36 \%$ dan $75 \%$ itu dikarenakan kebanyakan gambar di situs tersebut adalah gambar porn close up. Ini adalah kelemahan dari algoritma nude.js. Dugaan ini juga diperkuat dengan pengujian yang dilakukan oleh peneliti dengan 40 gambar yang meliputi 20 gambar porno dengan satu objek/poligon dan 20 gambar bebas bukan gambar porno. Dari pengujian tersebut diperoleh 20 gambar porno tersebut terdeteksi semua, sehingga dapat disimpulkan algoritma ini bagus untuk gambar dengan satu objek/poligon dan lemah pada gambar porn close up. Hasil pengklasifikasian pada gambar dengan kata kunci bukan porno yaitu wajah dan sapi juga cukup baik yaitu hanya $7.44 \%$ dan $9.48 \%$ terjadi kesalahan pendeteksian yaitu gambar bukan porno tapi terdeteksi sebagai gambar porno.

Secara keseluruhan hasil dari pengujian terhadap add-ons inetfilter ini cukup baik yaitu add-ons ini dapat menklasifikasikan gambar porno $81.70 \%$ akan tetapi juga ada tingkat kesalahan yang cukup tinggi yaitu $13.72 \%$.

\subsection{Kesimpulan}

\section{PENUTUP}

Total dari gambar yang diuji adalah 5762 gambar dengan 4010 gambar diprediksi gambar porno. Total gambar yang terdeteksi porno adalah 3276 gambar. Dengan demikian dari hasil pengujian disimpulkan bahwa addons inetfilter mampu mendeteksi gambar porno $81.70 \%$ dengan kesalahan pendeteksian sebesar $13.72 \%$. Jadi add-ons inetfilter cukup baik digunakan untuk pendeteksian dan pengeblock-an gambar porno.

\subsection{Saran}

Add-ons inetfilter dan juga library nude.js tidak sepenuhnya sempurna, masih banyak bug dan kekurangan. Ada beberapa saran dari peneliti yang akan bermanfaat untuk penelitian selanjutnya.

1. Library nude.js menggunakan fitur deteksi poligon sehingga gambar porno yang tidak berbentuk poligon seperti gambar close up itu tidak terdeteksi sebagai gambar porno.

2. Library nude.js menggunakan perhitungan canvas html sehingga ukuran gambar akan sangat berpengaruh baik dalam proses perhitungan pixel gambar maupun porses pengklasifikasian gambar. Bisa jadi ada dua gambar yang sama dengan ukuran yang berbeda itu terdeteksi salah satu sebagai gambar porno dan satunya tidak.

3. Library nude.js menggunakan teknik skin detection yaitu pendeteksian berdasarkan pixel warna kulit sehingga algoritma ini tidak berfungsi untuk gambar grayscale.

4. Add-ons inetfilter set intervalnya 500 milisecond. Set interval ini berpengaruh pada jeda proses looping, jika tidak dilakukan set interval maka looping akan sangat cepat dan tentu akan ada banyak gambar yang terlewati dari proses pengklasifikasian. Angka 500 milisecond adalah angka yang peneliti tentukan dan belum dilakukan pengujian apakah angka tersebut adalah angka yang paling baik untuk digunakan dalam add-ons ini.

\section{DAFTAR PUSTAKA}

[1] Sutoyo, 2009, Teori Pengolahan Citra Digital.Penerbit Andi:Yogyakarta.

[2] Armando, 2004, Mengupas Batas Pornografi. Meneg Pemberdayaan Perempuan Jakarta. 